\title{
Safety, Connectivity, and Comfortability as Improvement Indicators of Walkability to the Bus Stops in Penang Island
}

\author{
Nur Sabahiah Abdul Sukor \\ School of Civil Engineering \\ Engineering Campus \\ Universiti Sains Malaysia \\ Nibong Tebal, Pulau Pinang, Malaysia \\ cesabahiah@usm.my
}

\author{
Siti Fadhlina Muhammad Fisal \\ School of Civil Engineering \\ Engineering Campus \\ Universiti Sains Malaysia \\ Nibong Tebal, Pulau Pinang, Malaysia \\ fadhlinafisal@student.usm.my
}

\begin{abstract}
This study investigates the determinants of walkability by evaluating assessment indicators by constructing a path model based on on-site data collected in Penang. Based on the path analysis, safety $(\beta 2=0.691, t=9.301, \quad p<0.01)$ and connectivity $(\beta 1=0.559, t=8.048, \quad p<0.01)$ have a positive correlation to walkability. Meanwhile, walkability shows a negative correlation with the number of private vehicles. The findings of this study allow the authorities to focus on enhancing the safety of walking facilities that give access to bus stops which will probably increase the likeliness of using the public bus services. The findings from this study also reveal the underlying factors that can boost the public to adopt walking as an active mode of transport and thus reduce the dependency on private vehicles.
\end{abstract}

Keywords-walkability; Structural Equation Modelling (SEM); factor analysis; sustainable transport; public transport

\section{INTRODUCTION}

Walkability has many social and environmental benefits. Walking not only decreases the risk of obesity [1-6], but also prevents the incidence of other chronic diseases [7]. Nowadays, there is a decline in the walking behavior of people due to the increasing reliance on the use of private automobiles. Regardless of the negative health consequences that may arise, people still tend to rely on private vehicles instead of practicing active modes of transport. Apart from its negative health consequences, decreased practicing of active modes of transport has adverse consequences to the environment, such as air and noise pollution, while the number of fatal car accidents rises. Statistics from the World Health Organization (WHO) reported that Malaysia was ranked as one of the top three countries in the world with the deadliest roads after Thailand and South Africa [8]. A total of 7,152 deaths related to road accidents were recorded in Malaysia in the year 2016, mainly involving motorcyclists. One of the major factors of these accidents is of course the high reliance on vehicles for transportation. In conjunction with government's goal to achieve a 40:60 modal split, representing 40\% dependency on public transport and $60 \%$ on private vehicles by 2030 , the current high reliance on private vehicles should be alleviated immediately. In this study, the indicators related to walking facilities at bus stops were investigated for their association with the number of private vehicles. This study can be a future reference for transport engineers and planners to improve the accessibility for walking infrastructure and thus reduce the dependency on private vehicles.

\section{RELATED WORK}

The most influential factor on encouraging walkability is the accessibility to a good walking environment. Authors in [9] reported a few determinants of walking behavior such as land use mix, street connectivity, distance to transit stops, and destination accessibility. The walking behavior can also be associated with highly urbanized areas [10], destination types [11], and aesthetics factors on choosing a route for walking [12]. Another study reported that connectivity is an important attribute to ensure high-quality public transit [13]. Physical connectivity criteria such as continuously connected sidewalks and place-based barriers do affect the last-mile trip. Also, the origin and destination of the walking trip is one of the built-in environmental factors that affect the willingness to walk [14]. Walkability is also affected by factors such as walking distance, walking time, and the purpose of the trip [15]. In addition to the above factors, gender, age, marital status, shorter travel time and distance, income, education, and vehicle ownership were also claimed as contributing factors to walkability $[10,12,16,17]$. Safety is another feature that has been prioritized by pedestrians. Most motorcycle-taxi users are reluctant to walk because of safety concerns and most of them are afraid of accidents [18, 19]. A high rate of accidents involving pedestrians also discourages their willingness to walk which increases their dependency on vehicles. In addition, comfort is also associated with walkability: most people would like to walk if the walkway is comfortable [20]. This should be supported by good environmental design, proper space for walking, and good walking surfaces [21]. It is believed that comfortable walkways should be safe, with no obstacles, and smooth for strollers and wheelchair users [22].

The current study focuses on identifying the criteria that improve walkability, especially regarding the accessibility of public bus stations in Penang Island of Malaysia. The most 
significant criteria will be selected through path modeling analysis.

\section{RESEARCH METHODOLOGY}

\section{A. Data Collection}

The study was conducted along the proposed Bayan Lepas Light Rail Transit (BLLRT) in Penang Island. The aim of the study is to investigate the readiness of walking facilities to give access to the bus stops as one of the integrated links to the rail stations. Even though the proposed BLLRT alignment is still in the construction stage, this study can still be used as a baseline for further walkability studies. The proposed alignment for the rail network can be seen in [25]. In this study, the alignment was divided into 19 zones based on the location of the proposed train stations. One zone was considered to have $800 \mathrm{~m}$ radius by considering the maximum distance of willingness to walk to a train station $[18,23,24]$. In total, 123 bus stops located in all zones were identified and grouped as shown in Table I. The data collection involved two types of data: traffic count of private vehicles and a checklist's inspection results of the 123 bus stops. The private vehicle data were used as input (dependent variable) in the SEM Path Analysis. Meanwhile the scores in the checklists were applied as independent variables. The traffic count in this study was done in the morning and evening peak hours by considering only cars and motorcycles as private vehicles.

TABLE I. ZONES AND BUS STOPS INVOLVED IN THIS STUDY

\begin{tabular}{|l|c|c|c|}
\hline \multicolumn{2}{|c|}{ Zone ID } & Bus stop ID & No of bus stops \\
\hline 1 & Komtar Zone (K) & K1-K24 & 24 \\
\hline 2 & Macallum Zone (M) & M1-M9 & 9 \\
\hline 3 & Bandar Sri Pinang Zone (B) & B1-B8 & 8 \\
\hline 4 & Skycab Zone (S) & S1-S6 & 6 \\
\hline 5 & East Jelutong Zone (E) & E1-E4 & 4 \\
\hline 6 & The Light Zone (TL) & TL1-T7 & 7 \\
\hline 7 & Gelugor Zone (G) & G1-G3 & 3 \\
\hline 8 & USM Zone (USM) & USM1-USM3 & 3 \\
\hline 9 & Batu Uban Zone (BU) & BU1-BU9 & 9 \\
\hline 10 & Pesta Zone (P) & P1-P9 & 9 \\
\hline 11 & Sg Nibong Zone (SN) & SN1-SN7 & 7 \\
\hline 12 & Bukit Jambul Zone (BJ) & BJ1-BJ8 & 8 \\
\hline 13 & Spice Zone (SS) & SS1-SS8 & 8 \\
\hline 14 & Jalan Tengah Zone (JT) & JT1-JT9 & 9 \\
\hline 15 & Fiz North Zone (FN) & FN1-FN2 & 2 \\
\hline 16 & Fiz South Zone (FS) & FS1 & 1 \\
\hline 17 & Sg Tiram Zone (ST) & ST1-ST2 & 2 \\
\hline 18 & Penang Airport Zone (PA) & PA1-PA7 & 7 \\
\hline 19 & Permatang Damar Laut Zone (PDL) & PDL1-PDL2 & 2 \\
\hline & & & \\
\hline
\end{tabular}
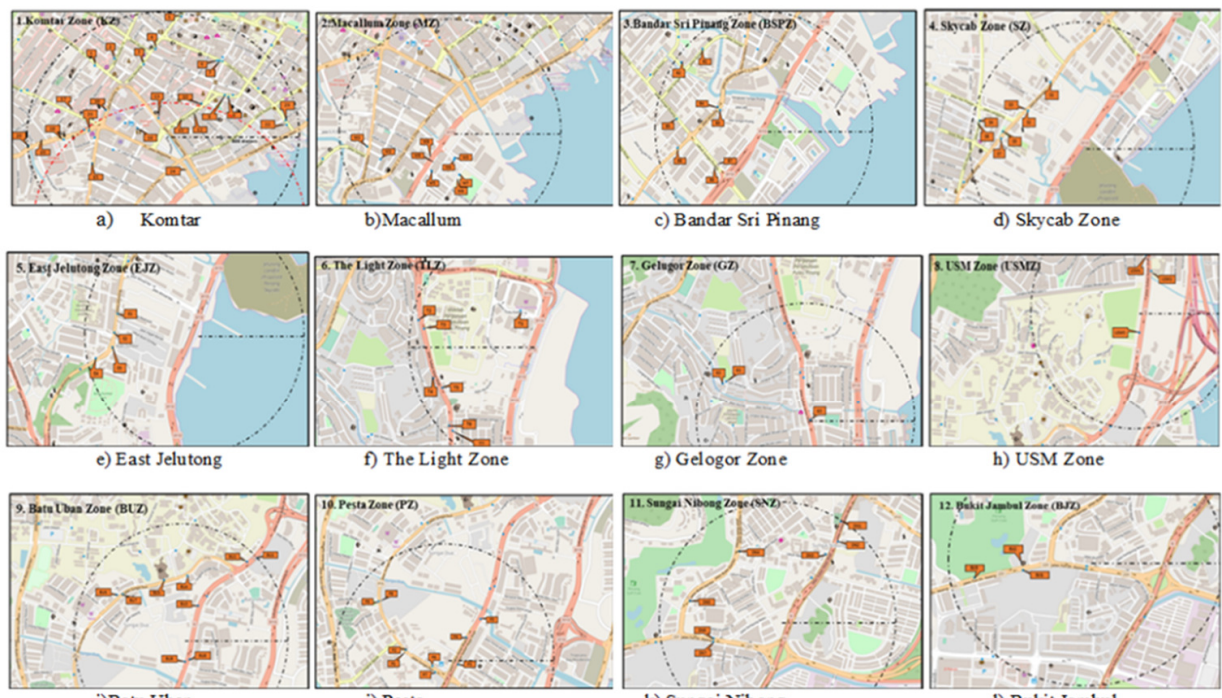

h) USM Zone
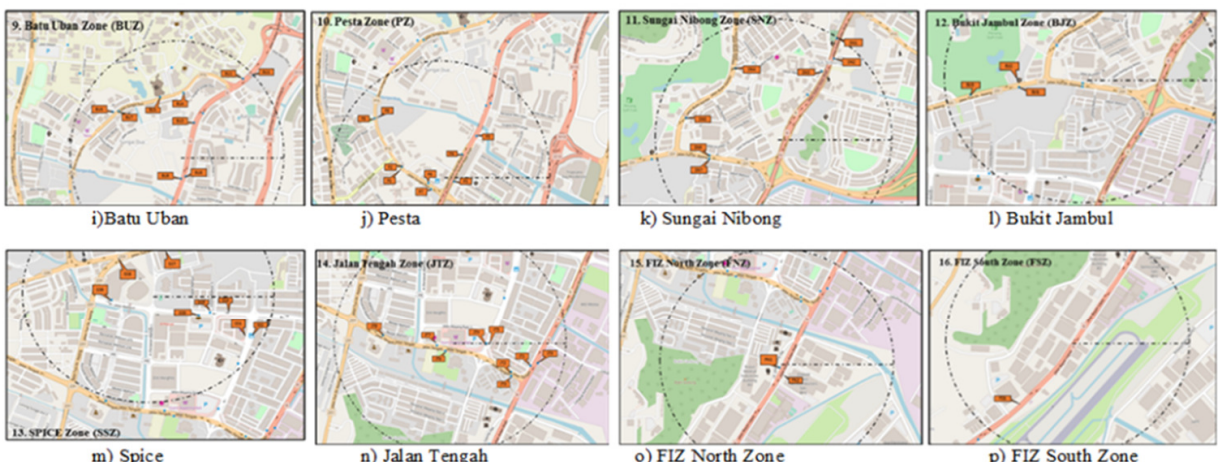

1) Bukit Jambu
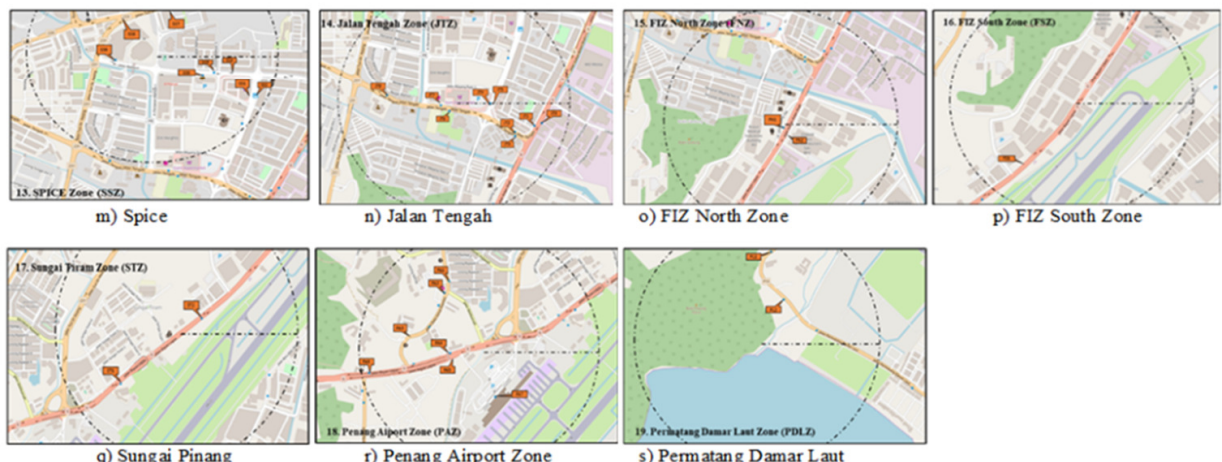

s) Permatang Damar Laut

Fig. 1. Location of 123 bus stops at 19 zones. 
Auditing tasks were done at the selected bus stops with the use of a checklist. The criteria for the walkability indicators in the checklist were taken from international guidelines, national guidelines, and previous studies shown in Table II. The indicators were audited based on the scores: $0=$ the indicator does not exist, $1=$ the indicator is available but not following the guidelines, and $2=$ the indicator is available and follows the guidelines. The results were inserted into the Statistical Package of Social Science (SPSS) for Factor Analysis. The checklist went through a pilot study and amendments were made to suit the specification of local context at 123 bus stops in Penang Island. Figure 2 shows briefly the way the design of the checklist was developed. A total of 18 indicators were identified.



Fig. 2. Brief framework on the audit procedure and design.

TABLE II. WALKABILITY VRITERIA

\begin{tabular}{|c|c|c|}
\hline $\begin{array}{c}\text { Indicator } \\
\text { ID }\end{array}$ & Walkability criteria & Source \\
\hline W1 & $\begin{array}{l}\text { Connecting pedestrian walkways either paved or } \\
\text { unpaved to the nearest main attraction within } 400 \mathrm{~m} \\
\text { of a bus stop }\end{array}$ & {$[26-30]$} \\
\hline W2 & The walkway should not be obstructed & {$[30,31]$} \\
\hline W3 & $\begin{array}{l}\text { Provision of bollards/shrubs/fences/ditches at the end } \\
\text { of the walkway to segregate it from the car lanes }\end{array}$ & \multirow{3}{*}[32]{} \\
\hline W4 & $\begin{array}{l}\text { Provision of bollards at road intersections (if there } \\
\text { are intersections) }\end{array}$ & \\
\hline W5 & $\begin{array}{l}\text { Provision of a median refuge island with a minimum } \\
\text { of } 1 \mathrm{~m} \text { width at crossings for roads that exceed } 2 \\
\text { lanes }\end{array}$ & \\
\hline W6 & Provision of a crosswalk at road intersections & [28] \\
\hline W7 & $\begin{array}{l}\text { Well maintained walkways (smooth pavement, not } \\
\text { overgrown shrubs, and not fallen trees) }\end{array}$ & {$[33]$} \\
\hline W8 & Signs in good condition (clearly seen/not broken) & {$[34,35]$} \\
\hline W9 & Crosswalk/markings are clearly seen & \multirow{2}{*}[29,32]{} \\
\hline $\mathrm{W} 10$ & Pedestrian signals must be in good condition & \\
\hline W11 & $\begin{array}{l}\text { Smooth incline at the end of walkways or towards } \\
\text { road intersections which can be used by wheelchair } \\
\text { users and strollers }\end{array}$ & {$[26,28]$} \\
\hline W12 & Seats at bus stops & \multirow{6}{*}[30,31]{} \\
\hline W13 & Rubbish bins at bus stops & \\
\hline W14 & Sidewalk width must not be less than $1.5 \mathrm{~m}$ & \\
\hline W15 & Availability of street trees/awnings/arcades & \\
\hline W16 & Provision of signs for the pedestrian walkway & \\
\hline W17 & $\begin{array}{l}\text { Provision of signs that warn motorists about the } \\
\text { presence of pedestrian walkways }\end{array}$ & \\
\hline W18 & $\begin{array}{l}\text { Provision of a divider of minimum } 1 \mathrm{~m} \text { width (low } \\
\text { shrubs/plants/fence/any safety barriers) between the } \\
\text { road and the walkway. }\end{array}$ & {$[28,34]$} \\
\hline
\end{tabular}

\section{B. Data Analysis}

This study aims to investigate the walkability indicators by developing a structural equation path model. SPSS was used for data computation and analysis. Data analysis was conducted in three stages which were: Exploratory Factor Analysis (EFA), Confirmatory Factor Analysis (CFA), and the development of PLS Path-Modelling.

\section{1) Exploratory Factor Analysis}

The EFA was conducted in order to investigate the relationship between the above mentioned indicators and walkability. EFA identifies the individual constructs and explores the consistency of the proposed latent factors with the actual data. The Principal Component Analysis (PCA) method was used to examine the factor loading among the measurement items for each factor. The value for factor loading of the measurement items should be more than the threshold of 0.5 . In this study, the evaluated indicators in the latent variables were extracted based on the output values of Kaiser-MeyerOlkin (KMO) measures. The components possessing higher factor loading of Kaiser criterion, i.e. more than 0.55 were accepted.

\section{2) Confirmatory Factor Analysis}

The CFA or reliability test was conducted based on internal consistency that consists of Composite Reliability (CR) and Cronbach's alpha value and convergent validity that composed of Average Variance Extracted (AVE). The acceptable value for Cronbach's alpha is 0.7 . However, it is suggested to accept lower values (0.6) in the research model [35]. The indicators should adhere the threshold of CR which is not more than 0.6 and AVE above 0.5 to be carried forward for path analysis. Factor loadings for indicator also should be above 0.6 .

\section{3) SEM Path Analysis}

The path model was constructed with a Structural Equation Model (SEM) by using SmartPLS 3.0 software. SEM-PLS was chosen because it can be applied for theoretical confirmation or theory development. Figure 3 shows the conceptual path model for walkability which consists of three latent variables (connectivity, comfort, safety) connecting to the dependent variable, i.e. the number of private vehicles. A total of 18 walkability indicators were constructed as underlying indicators for Independent Variables (IV). Meanwhile, the number of private vehicles collected from the traffic count was considered as the Dependent Variable (DV). This study aims to investigate the hypotheses below:

$\mathrm{H} 1$ : Connectivity is positively associated with walkability to the bus stop

$\mathrm{H} 2$ : Safety is positively associated with walkability to the bus stop

H3: Comfort is positively associated with walkability to the bus stop.

Positive association in this context means that the more the provision of evaluated indicators provided at the bus stop, the more the walkability element is promoted at the bus stop which has a tendency to attract people to walk and makes more likely the use of public buses. 


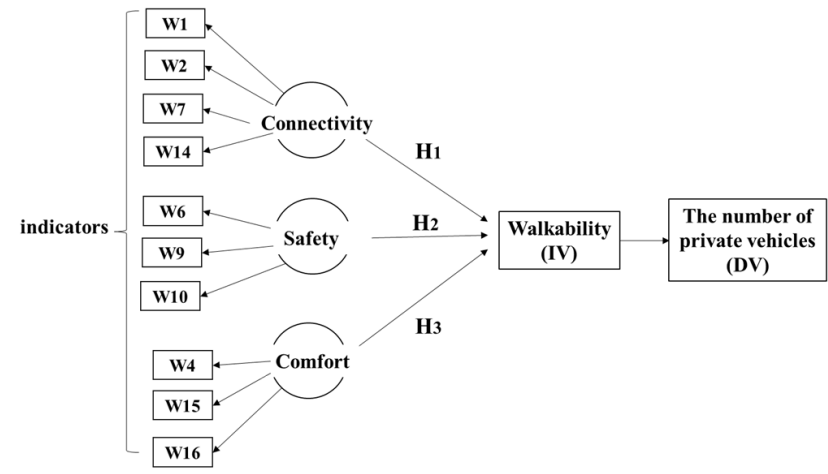

Fig. 3. Conceptual path model for walkability. IV: Independent Variable, DV: Dependent Variable.

\section{RESULTS AND DISCUSSION}

\section{A. EFA Results}

Before a model is constructed, factor analysis is implied to summarize the data by assessing the structure of variables for further analysis [36]. Theoretically, factor analysis was used to solve the problem by combining variables that are collinear [37]. A PCA was conducted on the 18 walkability indicators with oblique rotation (varimax). Meanwhile, the KMO measure verified the sampling adequacy for the analysis: $\mathrm{KMO}=0.733$ [38]. Based on Table III, all KMO values for the items were bigger than 0.7 , which is well above the limit of 0.50 . Bartlett's test $\left(\chi^{2}(153)=728.586, p<0.01\right)$ indicated that the correlation matrix is significantly different from an identity matrix, in which correlations between items are all zero and which is not random. Out of 18 indicators, 8 indicators were removed and indicators with factor loadings higher than 0.5 were considered highly correlated with the factors extracted and were retained.

TABLE III. KMO AND BARTLETT'S TEST RESULTS

\begin{tabular}{|c|c|c|}
\hline KMO measure of sampling adequacy & 0.733 \\
\hline \multirow{3}{*}{ Bartlett's test of sphericity } & Approx. $\boldsymbol{\chi}^{2}$ & 728.586 \\
\cline { 2 - 3 } & $\boldsymbol{d f}$ & 153 \\
\cline { 2 - 3 } & Sig. & 0.000 \\
\hline
\end{tabular}

\section{B. CFA Results}

Table IV shows the reliability and validity results of the constructed model. After CFA assessment, the indicators that surpassed the threshold value of factor loadings $(0.7)$ were only 6,3 belonging to connectivity (W2, W7, W14) and 3 to safety (W6, W9, W10). Notably, the variable comfort (W) was removed due to the low value of Cronbach's alpha which depicts that this variable is not reliable for further analysis. Connectivity and safety were found to fulfill all requirements by possessing a value of Cronbach's alpha higher than $0.6[39$, 40]. Meanwhile, values higher than 0.6 are suggested for indicator loadings [41, 42] and for composite reliability [43]. For Average Variance Extracted (AVE), 0.5 is the suggested threshold value [43] and values above this limit are considered acceptable. The results for connectivity and safety in Table IV confirm the convergent validity and good internal consistency of the measurement model.
TABLE IV. ASSESSMENT RESULTS OF THE MODEL

\begin{tabular}{|c|c|c|c|c|}
\hline Indicator & Cronbach's Alpha & Loadings & CR & AVE \\
\hline \multicolumn{5}{|c|}{ Connectivity } \\
\hline W2 & \multirow{3}{*}{0.766} & 0.844 & \multirow{3}{*}{0.864} & \multirow{3}{*}{0.680} \\
\hline W7 & & 0.859 & & \\
\hline W14 & & 0.768 & & \\
\hline \multicolumn{5}{|c|}{ Safety } \\
\hline W6 & \multirow{3}{*}{0.819} & 0.864 & \multirow{3}{*}{0.893} & \multirow{3}{*}{0.736} \\
\hline W9 & & 0.902 & & \\
\hline W10 & & 0.803 & & \\
\hline
\end{tabular}

\section{Path Analysis}

As shown in Figure 3, the latent variables safety and connectivity were related to the latent variable walkability, whereas walkability is related to the number of private vehicles. Meanwhile, connectivity and safety were connected to their respective indicators. Bootstrapping was performed on the model to test the significance of the relationships between adjacent constructs [44]. Based on Figure 4, the t-statistic for all independent variables satisfied the threshold value $(\mathrm{t} \geq 1.96, \mathrm{p}<0.05)$ [45]. All the $\mathrm{t}$-statistics are larger than 1.96 which shows that the variables are highly significant. Based on the result run by the PLS-Algorithm, safety shows a path coefficient value of $\beta 2=0.691(\mathrm{t}=9.301, \mathrm{p}<0.01)$ and connectivity $\beta 1=0.559(\mathrm{t}=8.048, \mathrm{p}<0.01)$. The path analysis shows positive results depicting the direct effect on walkability. Safety shows strong correlation due to the higher value, compared to connectivity, of the coefficient $\beta$ towards walkability. Hence, safety had a huge influence on walkability which is in accordance with the results in [46, 47]. Path analysis also shows a significant negative correlation of walkability towards the number of private vehicles $(\beta=-0.114$, $(t=1.208, p<0.05)$. This means that decreased provision of infrastructure for walkability element at a bus stop will be less likely to reduce the number of private vehicles passed in front of the bus stop. Inadequacy of high quality of public transportation is also argued to give impact on high dependency of private vehicles [48]. The indicators that can improve walkability at the bus stop are presented in Table V.

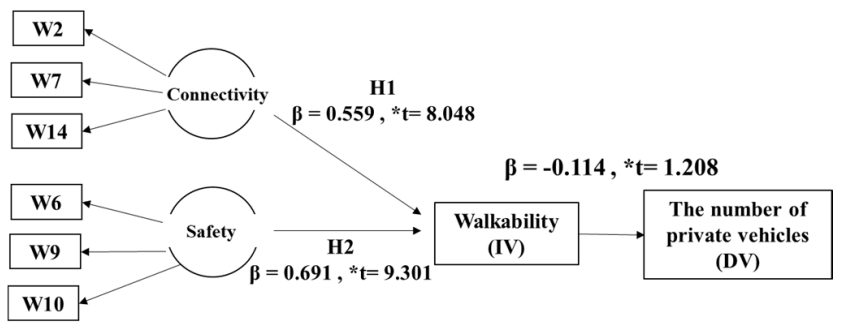

Fig. 4. The constructed path model for walkability.

TABLE V. INDICATORS WITH DESCRIPTION

\begin{tabular}{|c|l|}
\hline Indicator & \multicolumn{1}{c|}{ Description } \\
\hline W2 & The walkway should not be obstructed \\
\hline W7 & $\begin{array}{l}\text { Well maintained walkways (smooth pavement, not overgrown } \\
\text { shrubs, and not fallen trees) }\end{array}$ \\
\hline W14 & Sidewalk width must not be less than $1.5 \mathrm{~m}$ \\
\hline W6 & Provision of a crosswalk at road intersections \\
\hline W9 & Crosswalk/markings are clearly seen \\
\hline W10 & Pedestrian signals must be in good condition \\
\hline
\end{tabular}




\section{CONCLUSION}

In this study, walkability is proven to be negatively significant towards the number of private vehicles. It means that the provision of better walking facilities will reduce the number of private vehicles being used. It is also indicating that the infrastructure at the bus stop should be enhanced. The findings show that safety has the strongest correlation towards walkability depicting that walking facilities should be safe in terms of provision of crosswalk, road markings, and pedestrian signals. This is concurrent with the findings of previous studies which showed that upgrading the walking infrastructure will increase the likeliness to walk [14, 50-51]. However, most of the previous studies were based on the preferences of users [22, 52], whereas this study focuses more on auditing the walking facilities according to the guidelines.

As a conclusion, all the indicators that significantly affecting the likeliness to walk can be suggested to be included in the improvised version of traffic assessment guidelines, especially in Malaysia. This could simultaneously improve the quality to access the bus stops which may reduce the reliance on private vehicles. For countries that practice Traffic Impact Assessment (TIA), these indicators could enhance the traffic study before one development project being endorsed.

\section{ACKNOWLEDGMENT}

This study was funded by the Transdisciplinary Research Grant Scheme (TRGS) from the Ministry of Higher Education, MOHE (203/PAWAM/67610002).

\section{REFERENCES}

[1] L. D. Frank, J. F. Sallis, T. L. Conway, J. E. Chapman, B. E. Saelens, and W. Bachman, "Many Pathways from Land Use to Health: Associations between Neighborhood Walkability and Active Transportation, Body Mass Index, and Air Quality," Journal of the American Planning Association, vol. 72, no. 1, pp. 75-87, Mar. 2006, https://doi.org/10.1080/01944360608976725.

[2] B. Giles-Corti, P. Hooper, S. Foster, J. Koohsari, and J. Francis, Low density development: Impacts on physical activity and associated health outcomes. Melbourne, Australia: National Heart Foundation of Australia, 2014.

[3] R. H. Glazier et al., "Density, Destinations or Both? A Comparison of Measures of Walkability in Relation to Transportation Behaviors, Obesity and Diabetes in Toronto, Canada," PLoS one, vol. 9, no. 1, Jan. 2014, Art. no. e85295, https://doi.org/10.1371/journal.pone.0085295.

[4] G. L. Booth et al., "Unwalkable neighborhoods, poverty, and the risk of diabetes among recent immigrants to Canada compared with long-term residents," Diabetes Care, vol. 36, no. 2, pp. 302-308, Feb. 2013, https://doi.org/10.2337/dc12-0777.

[5] M. I. Creatore et al., "Association of Neighborhood Walkability With Change in Overweight, Obesity, and Diabetes," JAMA, vol. 315, no. 20, p. 2211, May 2016, https://doi.org/10.1001/jama.2016.5898.

[6] M. Chiu, B. R. Shah, L. C. Maclagan, M.-R. Rezai, P. C. Austin, and J. V. Tu, "Walk Score ${ }^{\circledR}$ and the prevalence of utilitarian walking and obesity among Ontario adults: A cross-sectional study," Health Reports, vol. 26 , no. 7 , pp. $3-10$, Jul. 2015.

[7] R. Rafiemanzelat, M. I. Emadi, and A. J. Kamali, "City sustainability: the influence of walkability on built environments," Transportation Research Procedia, vol. 24, pp. 97-104, Jan. 2017, https://doi.org/10.1016/j.trpro.2017.05.074.

[8] T. Ruxyn, "Death Rates On Malaysian Roads Is 3rd Highest Globally, More Than China And India," SAYS, Jun. 21, 2017. https://says.com/my/news/malaysia-s-roads-among-the-world-s-mostdangerous-and-deadliest (accessed Nov. 07, 2020).
[9] D. S. Vale and M. Pereira, "Influence on pedestrian commuting behavior of the built environment surrounding destinations: A structural equations modeling approach," International Journal of Sustainable Transportation, vol. 10, no. 8, pp. 730-741, Sep. 2016, https://doi.org/10.1080/15568318.2016.1144836.

[10] G. Corpuz, A. Hay, and D. Merom, “, Grace, Annette Hay, and Dafna Merom. 'Walking for transport and health: Trends in Sydney in the last decade.," " presented at the 28th Australasian Transport Research Forum, Sydney, Australia, 2005.

[11] C. Townsend and J. Zacharias, "Built environment and pedestrian behavior at rail rapid transit stations in Bangkok," Transportation, vol. 37, no. 2, pp. 317-330, Mar. 2010, https://doi.org/10.1007/s11116-0099226-8.

[12] A. W. Agrawal, M. Schlossberg, and K. Irvin, "How Far, by Which Route and Why? A Spatial Analysis of Pedestrian Preference," Journal of Urban Design, vol. 13, no. 1, pp. 81-98, Feb. 2008, https://doi.org/ $10.1080 / 13574800701804074$.

[13] N. Tilahun, S. Yin, M. Li, and Y. Keita, "Mapping Metropolitan Chicago's Accessibility," University of Illinois at Chicago, Chicago, IL, USA, 2015.

[14] P. Maghelal and C. J. Capp, "Walkability: A Review of Existing Pedestrian Indices," URISA Journal, vol. 23, no. 2, pp. 5-19, Jan. 2011.

[15] N. S. Abdul Sukor and S. Muhammad Fisal, "Factors influencing the willingness to walk to the bus stops in Penang Island," Planning Malaysia, vol. 16, no. 5, pp. 193-204, Jul. 2018, https://doi.org/ 10.21837/pmjournal.v16.i5.423.

[16] R. Daniels and C. Mulley, "Explaining walking distance to public transport: The dominance of public transport supply," Journal of Transport and Land Use, vol. 6, no. 2, pp. 5-20, Aug. 2013, https://doi.org/10.5198/jtlu.v6i2.308.

[17] A. L. Freeland, S. N. Banerjee, A. L. Dannenberg, and A. M. Wendel, "Walking associated with public transit: moving toward increased physical activity in the United States," American Journal of Public Health, vol. 103, no. 3, pp. 536-542, Mar. 2013, https://doi.org/ 10.2105/AJPH.2012.300912.

[18] P. Pongprasert and H. Kubota, "Switching from motorcycle taxi to walking: A case study of transit station access in Bangkok, Thailand," IATSS Research, vol. 41, no. 4, pp. 182-190, Dec. 2017, https://doi.org/ 10.1016/j.iatssr.2017.03.003.

[19] D. Simons, P. Clarys, I. De Bourdeaudhuij, B. de Geus, C. Vandelanotte, and B. Deforche, "Why do young adults choose different transport modes? A focus group study," Transport Policy, vol. 36, pp. 151-159, Nov. 2014, https://doi.org/10.1016/j.tranpol.2014.08.009.

[20] T. Litman, "Economic Value of Walkability," Transportation Research Record, vol. 1828, no. 1, pp. 3-11, Jan. 2003, https://doi.org/ 10.3141/1828-01.

[21] R. Kumar, Walkability of Neighborhoods: A Critical Analysis of the Role Played by Zoning Codes in Creating a Walkable Environment. Saarbrücken, Germany: LAP LAMBERT Academic Publishing, 2010.

[22] J. Zakaria and N. Ujang, "Comfort of Walking in the City Center of Kuala Lumpur," Procedia - Social and Behavioral Sciences, vol. 170, pp. 642-652, Jan. 2015, https://doi.org/10.1016/j.sbspro.2015.01.066.

[23] J. Ji and X. Gao, "Analysis of people's satisfaction with public transportation in Beijing," Habitat International, vol. 34, no. 4, pp. 464 470, Oct. 2010, https://doi.org/10.1016/j.habitatint.2009.12.003.

[24] I. Ker and S. Ginn, "Myths and realities in walkable catchments: the case of walking and transit," in Publication of: ARRB Transport Research, Limited, 2003, Accessed: Nov. 07, 2020. [Online]. Available: https://trid.trb.org/view/665133.

[25] "Penang Master Plan - Penang." http://pgmasterplan.penang.gov.my/ (accessed Nov. 07, 2020).

[26] "West Sussex County Council Transport Assessment Methodology." West Sussex County Council, Jun. 2017.

[27] B. E. Phillips and P. Joyce, "Ryerson Church Transportation Assessment and Management Study," Bunt \& Associates, Vancouver, Canada, 4827-07, Dec. 2016 
[28] Transport assessment - guidelines for development proposals in Northern Ireland. Belfast, UK: Department of the Environment for Northern Ireland, 2006.

[29] "Transport Assessment, Granta Park Phase II," Glanville, Oxfordshire, UK, 2010.

[30] "TOD Standard - Institute for Transportation and Development Policy," ITDP. https://www.itdp.org/2017/06/23/tod-standard/.

[31] Pedestrian planning and design guide. New Zealand: NZ Transport Agency, 2009.

[32] K. McNally, "Design Guidelines for Walkable Communities," Niehoff Studio, University of Cincinnati, Cincinnati, OH, USA, Jan. 2010.

[33] Transport Assessment Guidance. Glasgow, UK: Transport Scotland, 2012.

[34] Garis Panduan Perancangan Kejiranan Hijau. Malaysia: Jabatan Perancangan Bandar dan Desa Semenanjung Malaysia, Kementerian Perumahan dan Kerajaan Tempatan, 2012.

[35] J. F. J. Hair, W. C. Black, B. J. Babin, and R. E. Anderson, Multivariate Data Analysis, 7th ed. Upper Saddle River, NJ, USA: Pearson, 2009.

[36] T. Cleff, "Univariate Data Analysis," in Exploratory Data Analysis in Business and Economics: An Introduction Using SPSS, Stata, and Excel, T. Cleff, Ed. Cham: Springer International Publishing, 2014, pp. 23-60.

[37] A. Field, Discovering Statistics Using SPSS, 3rd Edition, 3rd ed. Los Angeles, CA, USA: SAGE Publications Ltd, 2009.

[38] J. F. Hair Jr, M. Sarstedt, L. Hopkins, and V. G. Kuppelwieser, "Partial least squares structural equation modeling (PLS-SEM): An emerging tool in business research," European Business Review, vol. 26, no. 2, pp. 106-121, Jan. 2014, https://doi.org/10.1108/EBR-10-2013-0128.

[39] J. Hair, G. T. M. Hult, C. M. Ringle, and M. Sarstedt, A Primer on Partial Least Squares Structural Equation Modeling, 1st ed. Los Angeles, CA, USA: SAGE Publications, Inc, 2013.

[40] W. Chin, "Issues and Opinion on Structural Equation Modeling," MIS Quarterly, vol. 22, no. 1, Mar. 1998.

[41] J. Henseler, C. M. Ringle, and R. R. Sinkovics, "The use of partial least squares path modeling in international marketing," in New Challenges to International Marketing, vol. 20, R. R. Sinkovics and P. N. Ghauri, Eds. Emerald Group Publishing Limited, 2009, pp. 277-319.

[42] J. F. Hair, C. M. Ringle, and M. Sarstedt, "PLS-SEM: Indeed a Silver Bullet," Journal of Marketing Theory and Practice, vol. 19, no. 2, pp. 139-152, Apr. 2011, https://doi.org/10.2753/MTP1069-6679190202.

[43] C. Fornell and D. F. Larcker, "Structural Equation Models with Unobservable Variables and Measurement Error: Algebra and Statistics," Journal of Marketing Research, vol. 18, no. 3, pp. 382-388, Aug. 1981, https://doi.org/10.2307/3150980.

[44] S. Streukens and S. Leroi-Werelds, "Bootstrapping and PLS-SEM: A step-by-step guide to get more out of your bootstrap results," European Management Journal, vol. 34, no. 6, pp. 618-632, Dec. 2016, https://doi.org/10.1016/j.emj.2016.06.003.

[45] K. Wong, "Partial least square structural equation modeling (PLS-SEM) techniques using SmartPLS," Marketing Bulletin, vol. 24, pp. 1-32, Jan. 2013.

[46] O. L. H. Leh, N. I. Z. Hasri, and S. N. A. M. Musthafa, "Residents' transportation mode preferences in Transit Oriented Area: A case study of Mentari Court, Petaling Jaya, Malaysia," Geografia-Malaysian Journal of Society and Space, vol. 12, no. 1, Sep. 2017

[47] E. Shay, C. Spoon, and A. Khattak, "Walkable Environments and Walking Activity," University of Tennessee, Knoxville, TN, USA, Jan. 2004.

[48] A. Jawed, M. a. H. Talpur, I. A. Chandio, and P. N. Mahesar, "Impacts of In-Accessible and Poor Public Transportation System on Urban Enviroment: Evidence from Hyderabad, Pakistan," Engineering, Technology \& Applied Science Research, vol. 9, no. 2, pp. 3896-3899, Apr. 2019, https://doi.org/10.48084/etasr.2482.

[49] S. Gori, M. Nigro, and M. Petrelli, "Walkability Indicators for Pedestrian-Friendly Design," Transportation Research Record, vol. 2464, no. 1, pp. 38-45, Jan. 2014, https://doi.org/10.3141/2464-05.

[50] E. Papa and L. Bertolini, "Accessibility and Transit-Oriented Development in European metropolitan areas," Journal of Transport
Geography, vol. 47, pp. 70-83, Jul. 2015, https://doi.org/10.1016/j.jtrangeo.2015.07.003.

[51] N. Abdul Ghani, T. Shimizu, and S. Mokhtar, "Assessment of Pedestrian Facilities in Malacca World Heritage Site, Malaysia using P-Index Method," Journal of the Eastern Asia Society for Transportation Studies, vol. 11, pp. 1535-1554, 2015, https://doi.org/10.11175/ easts.11.1535.

[52] S. Makki, M. Surat, A. I. Che-Ani, H. Farkisch, and H. R. Mokhtarian, "The importance of design characteristics in walking from student's perspective: a case study in Universiti Kebangsaan Malaysia," Journal of Building Performance, vol. 3, no. 1, pp. 42-49, 2012. 